\title{
Macrophage origin of Reed-Sternberg cells: an immunohistochemical study
}

\author{
SV PAYNE, DH WRIGHT, KJM JONES, MA JUDD \\ From the Department of Pathology, Level E, South Pathology Block, Southampton General Hospital, \\ Southampton SO9 $4 X Y$
}

SUMMARY In an immunohistochemical study of 26 biopsies from 24 patients with Hodgkin's disease a granular staining pattern for alpha-1-antitrypsin $\left(\alpha_{1} \mathrm{AT}\right)$ and alpha-1-antichymotrypsin $\left(\alpha_{1} \mathrm{ACT}\right)$ was seen in Reed-Sternberg (RS) cells and mononuclear Hodgkin's $(\mathrm{H})$ cells in over half the cases. The pattern of staining for these antiproteases seen in RS and $\mathrm{H}$ cells has previously only been observed in normal and malignant cells of the monocyte/macrophage lineage within the lymphoreticular system. A faintly granular evenly distributed staining for IgG was found in viable $\mathrm{RS}$ and $\mathrm{H}$ cells. This staining was associated with a similar distribution of both light chains but not $J$ chain, suggesting that the immunoglobulin had not been synthesised by these cells but had been taken up from the extracellular environment. It is suggested that this uptake is an active process occurring in viable $\mathrm{RS}$ and $\mathrm{H}$ cells, possibly via Fc $\gamma$ receptors and further supports an origin from cells of the monocyte/macrophage lineage. $\operatorname{IgA}$, IgD, albumin, fibrinogen, Clq, C4 and C 3 were present in some cells, IgM was more rarely found and lysozyme was absent. The fact that cells staining for these serum proteins generally showed signs of degeneration and that the extent of staining correlated with the molecular weight, but not serum concentration, of the protein suggests that they are passively acquired by dead or dying cells and thus represent a separate phenomenon from IgG uptake. The function of IgG uptake and accumulation by RS cells and the $\alpha_{1} \mathrm{AT}$ and $\alpha_{1} \mathrm{ACT}$ markers may prove of use in identifying the macrophage subtype from which these cells are derived.

An understanding of the origin of Reed-Sternberg (RS) cells is central to our understanding of the interaction of these tumour cells with the accompanying reactive lymphoid and histiocytic elements and of the relevance of these interactions to the pathogenesis of Hodgkin's disease. Ultrastructural evidence has been inconclusive since it has been interpreted as indicating both a histiocytic $^{12}$ and lymphocytic origin. ${ }^{34}$ The presence of non-specific esterase and acid phosphatase favours a histiocytic origin ${ }^{5} \mathbf{6}$ although staining for peroxidase, lysozyme and with antimacrophage serum has proved negative. ${ }^{6} 7$ The establishment of cell lines with macrophage-like features from Hodgkin's tissue $^{89}$ and the demonstration that in vitro RS cells have phagocytic potential ${ }^{10}$ suggests that these cells have more in common with macrophages than lymphocytes. More specifically a dendritic pattern seen with Marshall's metalophil stain has been interpreted as showing identity with dendritic reticulum cells. ${ }^{11}$

Accepted for publication 2 July 1981
Attention has focused on the identification of surface and cytoplasmic IgG on RS cells ${ }^{12-16}$ taken by some as indicative of a derivation from $\mathrm{B}$ lymphocytes. ${ }^{7}$ However, since this IgG is associated with both light chains within individual cells it seems more likely that rather than having been synthesised it has been acquired from an exogenous source. ${ }^{1017}$ Ultrastructural studies have not confirmed this however, since electron microscope immunoperoxidase preparations have shown a cytoplasmic granular product not related to endocytic structures. This distribution has been interpreted as indicating both specific ribosomal synthesis ${ }^{1819}$ and nonspecific leakage into the cell. ${ }^{17}$ Other serum proteins have been found in RS cells but less commonly than IgG. ${ }^{15-17}$

In the light of the conflicting interpretations as to the extent and significance of IgG and other proteins in $\mathrm{RS}$ cells we have performed an immunoperoxidase study of 12 different serum proteins including IgG, on a series of biopsies from patients with Hodgkin's disease. We have stained for $\mathbf{J}$ chain which although associated extracellularly only with dimeric IgA and 
$19 \mathrm{~S} \mathrm{IgM} \mathrm{is} \mathrm{synthesised} \mathrm{in} \mathrm{cells} \mathrm{producing} \mathrm{immuno-}$ globulin of all classes. ${ }^{20-22}$ The association of $\mathrm{J}$ chain with intracellular IgG is therefore indicative of immunoglobulin synthesis, lack of such an association may reflect uptake of serum protein. A characteristic staining pattern for alpha-1-antitrypsin $\left(\alpha_{1} \mathrm{AT}\right)$ has proved to be a useful marker for cells of the macrophage series. ${ }^{2324} \mathrm{We}$ have, therefore, looked critically at the staining pattern in RS cells for this antiprotease and for the related inhibitor, alpha-1-antichymotrypsin $\left(\alpha_{1} \mathrm{ACT}\right)$.

\section{Material and methods}

Twenty-six biopsies from 24 Hodgkin's patients were studied. Twenty-one biopsies were of the nodular sclerosing type, one was lymphocyte and histiocyte predominant and two showed mixed cellularity.

Sections were cut from routine formalin-fixed paraffin embedded material, deparaffinised in xylol and absolute alcohol and treated with $0.5 \%$ hydrogen peroxidase in methanol to block endogenous peroxidase activity. Sections were then treated according to the trypsin/peroxidase-antiperoxidase (PAP) method. ${ }^{25}$ Briefly, they were incubated with $\mathbf{0 . 1} \%$ trypsin (Sigma Chemical Company, Poole) in $0.1 \% \mathrm{CaCl}_{2}, \mathrm{pH} 7 \cdot 8$, at $37^{\circ} \mathrm{C}$ for 15 min followed by washing in distilled water and TRIS- $\mathrm{NaCl}$. They were then stained for a variety of proteins by first incubating with specific rabbit antisera (Behringwerke AG, Marbug-Lahn) followed by swine antirabbit Ig and PAP complexes (Dakopatts AS, Copenhagen). Rabbit antisera specific for the following proteins were used as first layers: $\gamma, \mu, \delta, \alpha, \kappa$ and $\lambda$ Ig chains, J chain and $\alpha_{1} \mathrm{AT}, \alpha_{1} \mathrm{ACT}, \mathrm{C} 3, \mathrm{C} 4$, $\mathrm{C} 1 \mathrm{q}$ and lysozyme. Suitable dilutions of these anti- sera were established by staining control tissues. Sites of peroxidase activity were then developed with diaminobenzidene and sections counterstained with haematoxylin. Control sections were treated with normal rabbit serum in place of specific antiserum.

The specificity of the rabbit antisera was established by radial immunodiffusion and immunoelectrophoresis. The antihuman Ig sera were further tested against defined antigen substrate spheres, ${ }^{26}$ provided by Professor G Stevenson of the Tenovus Research Laboratory, Southampton. The specificity of the anti-J chain, anti-lysozyme and anti- $\alpha_{1}$ AT sera was confirmed by absorption of activity with purified $\mathrm{J}$ chain, lysozyme and $\alpha_{1} \mathrm{AT}$, respectively. Competitive blocking of staining for $\mathrm{Clq}, \mathrm{C} 3, \mathrm{C} 4$, albumin and fibrinogen by goat antisera (Nordic Immunology, Tilburg) established the specificity of these antisera.

\section{Results}

IgG was present in $\mathrm{RS}$ cells and mononuclear $\mathrm{H}$ cells in 26/26 biopsies and both light chains were detected in similar numbers of cells in $25 / 26$ cases (Table). The proportion of IgG-positive RS and $\mathrm{H}$ cells varied considerably between biopsies; the numbers of biopsies in which $<5 \%, 5-30 \%$ and $>30 \%$ of RS cells were positive being $31 \%, 42 \%$ and $27 \%$ respectively. Hence in the majority of biopsies less than $30 \%$ of RS and $\mathrm{H}$ cells contained IgG. The staining varied in intensity between neighbouring RS cells, was usually less intense than that of surrounding plasma cells and was in two basic patterns. The majority of positive cells were of type I in which the reaction product was faintly granular and distributed evenly throughout the cytoplasm

Extent of staining for 12 serum proteins, $\kappa, \lambda$, and J chains in Reed-Sternberg cells and mononuclear Hodgkin's cells

\begin{tabular}{|c|c|c|c|}
\hline Protein & Molecular weight $\left(\times 10^{-3}\right)$ Serum concentration $(\mathrm{mg} / 100 \mathrm{ml})$ & Cases positive/cases studied & $\%$ Cases positive \\
\hline \multicolumn{4}{|c|}{ (a) Type I granular staining of viable cells and type II marginated staining of degenerate cells } \\
\hline IgG & 150 & $26 / 26$ & 100 \\
\hline IgA & 160 & $12 / 26$ & $46 \cdot 2$ \\
\hline IgM & 900 & $2 / 26$ & $7 \cdot 7$ \\
\hline IgD & 170 & $5 / 26$ & $22 \cdot 7$ \\
\hline$\kappa$ chain & & $25 / 26$ & $96 \cdot 2$ \\
\hline$\lambda$ chain & & $25 / 26^{*}$ & $96 \cdot 2$ \\
\hline $\mathrm{J}$ chain & & $3 / 23$ & $13 \cdot 0$ \\
\hline $\mathrm{Clq}$ & 400 & $3 / 19$ & $15 \cdot 8$ \\
\hline C3 & 185 & $11 / 22$ & 50.0 \\
\hline C4 & 230 & $4 / 21$ & $19 \cdot 0$ \\
\hline Albumin & 4400 & $16 / 25$ & $64 \cdot 0$ \\
\hline Fibrinogen & 300 & $6 / 21$ & $28 \cdot 6$ \\
\hline$\alpha_{1} \mathbf{A T}$ & 290 & $19 / 24$ & $79 \cdot 2$ \\
\hline$\alpha_{1} \mathbf{A C T}$ & 45 & $12 / 17$ & $70 \cdot 6$ \\
\hline Lysozyme & 15 & $0 / 21$ & 0 \\
\hline \multicolumn{4}{|c|}{ (b) Staining as an accumulation of granules adjacent to the nucleus } \\
\hline$\alpha_{1} \mathbf{A T}$ & & $13 / 24$ & $54 \cdot 2$ \\
\hline$\alpha_{1} \mathbf{A C T}$ & & $11 / 17$ & $64 \cdot 7$ \\
\hline
\end{tabular}

*Very weak staining in a few cells. 


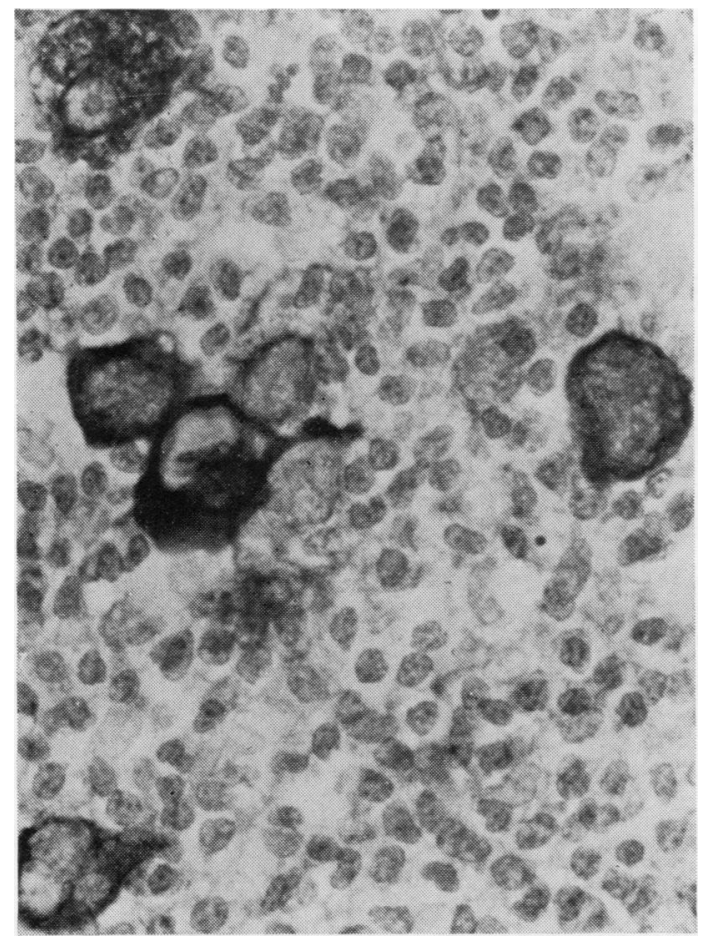

Fig. 1 Reed-Sternberg and mononuclear Hodgkin's cells. Note the faintly granular quality of staining in the less intensely stained cells, the viable nature of the positive cells and the staining of cytoplasmic processes extended in between neighbouring cells $\times 640$.

with no localisation to the perinuclear space or cell margin. The cytoplasm of these cells extended up to and in between neighbouring cells and the nuclei were intact (Figs. 1 \& 2). In cells of type II the cytoplasm had usually retracted away from neighbouring cells, the nucleus was dark and shrunken and the peroxidase stain was diffuse, darker than in type $I$ and more concentrated at the retracted margin of the cell (Fig. 4).

IgA-positive $\mathrm{RS}$ and $\mathrm{H}$ cells were seen in $12 / 26$ biopsies and IgD-positive cells in 5/22 (Table). IgA and $\operatorname{IgD}$ was present in only a minority of RS and $\mathrm{H}$ cells and the staining in these cells was usually of type II although occasionally of type 1 . Staining for IgM and $J$ chain was negative with the exception of a few shrunken cells positive for IgM in two cases and the occasional cell weakly positive for $J$ chain in three cases (Fig. 3). In 2/3 J chain-positive cases IgMor IgA-positive RS cells, or both, were also detected. Staining for lysozyme was consistently negative in RS cells but RS cells staining for all other proteins tested, namely C1q, C3, C4, albumin, fibrinogen, $\alpha_{1} \mathrm{AT}$ and $\alpha_{1} \mathrm{ACT}$ were present in some biopsies
(Table). The staining for these proteins was similar to that of IgA and IgD in that it was present in a minority of cells and was predominantly of type II. With the exception of IgG, which was present in all cases, and lysozyme, which was present in none, there was a positive correlation between the proportion of cases containing $\mathrm{RS}$ and $\mathrm{H}$ cells staining for each protein and the molecular weight of the protein (Table); the smaller proteins being more commonly found. There was no such correlation between the extent of staining and serum concentration.

In addition to the diffuse staining for $\alpha_{1} \mathrm{AT}$ in degenerating cells in $79 \%$ of cases a distinctive staining pattern, unlike that of the other proteins, was found in RS and $\mathrm{H}$ cells in over half the cases studied (Table). The staining in these cells was localised as an accumulation of granules adjacent to the nucleus or tucked into a nuclear indentation (Fig. 5). This pattern of staining was also seen in reactive histiocytes and in normal peripheral blood monocytes (Fig. 6). The proportion of RS and $\mathrm{H}$ cells that stained in this pattern varied considerably between biopsies. In a few cases more than $50 \% \mathrm{RS}$ and $\mathrm{H}$ cells were positive but in most cases only a minority were stained. A similar staining pattern for $\alpha_{1}$ ACT was seen in RS and $H$ cells in 11/17 cases (Fig. 5). Reactive histiocytes and monocytes stained for $\alpha_{1}$ ACT in an identical pattern to $\alpha_{1}$ AT.

Plasma cells were common in Hodgkin's tissue; the frequency of heavy chain classes being $\gamma<\alpha<\mu$ $<\delta$. There was no positive correlation between plasma cell numbers and immunoglobulin positive RS cells, an inverse relation between these two cells being more commonly observed.

\section{Discussion}

Many RS cells contain polytypic IgG. ${ }^{7} 1017$ Ultrastructural studies have produced conflicting evidence as to whether this immunoglobulin is associated with ribosomes ${ }^{17-19}$ and since it does not appear to be associated with endocytotic structures it is not clear whether it has been synthesised or acquired by these cells. Other immunoglobulins, albumin, $\alpha_{1} \mathrm{AT}$ and $\alpha_{1}$ ACT, have also been found within RS cells ${ }^{10}$ 15-17 but reports of their incidence vary widely and little attention has been paid to their staining pattern or cytoplasmic distribution. In this study we have shown that 11 serum proteins other than IgG can be demonstrated in RS cells but that, contrary to other reports, ${ }^{17}$ their incidence and staining pattern differ from IgG and they are thus thought to represent a different phenomenon.

The proteins detected, in their order of frequency, were $\alpha_{1} \mathrm{AT}, \alpha_{1} \mathrm{ACT}$, albumin, C3, IgA, fibrinogen, 

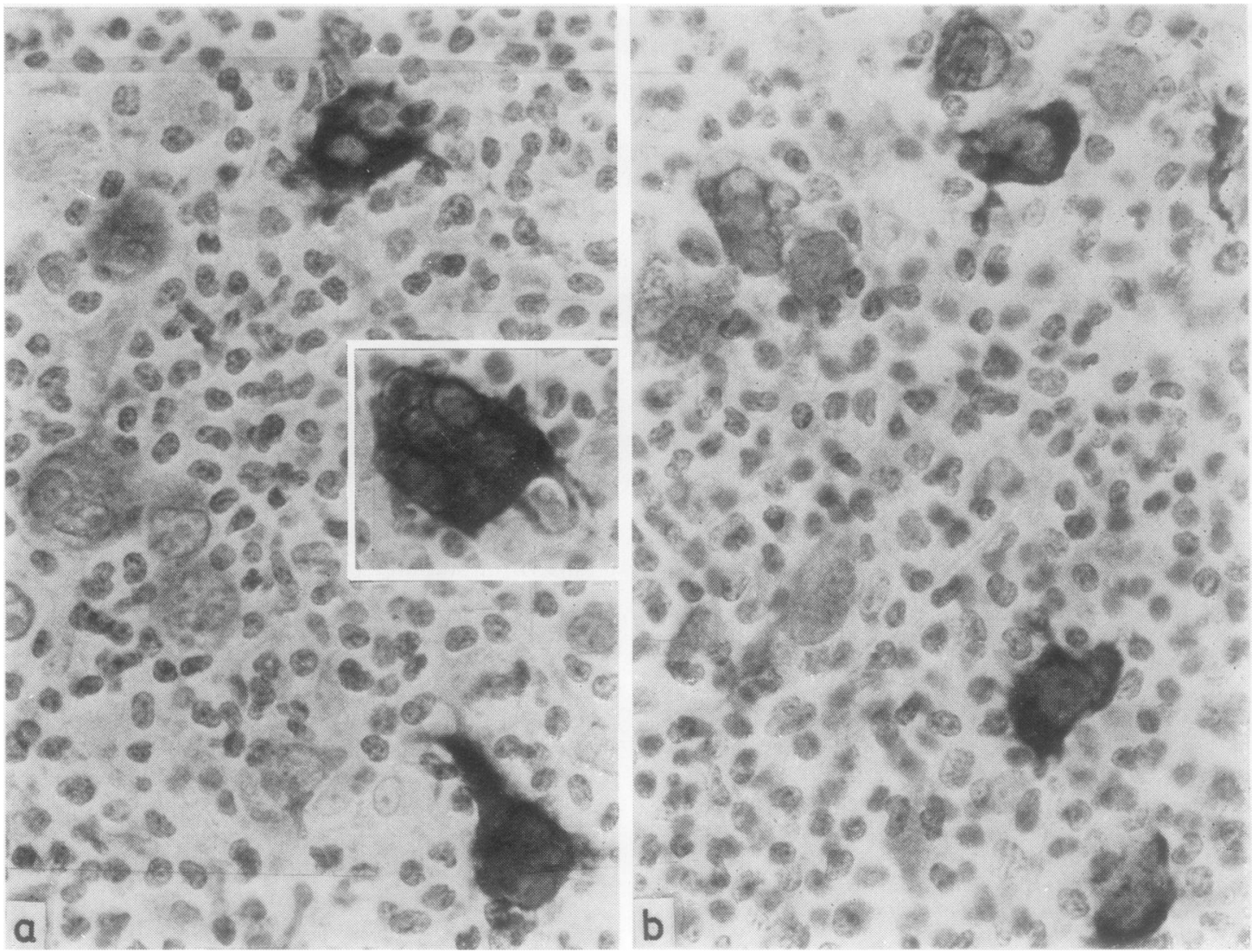

Fig. 2 Staining for $(a) \kappa$ and $(b) \lambda$ light chains within Reed-Sternberg and mononuclear Hodgkin's cells. The staining is similar to that of IgG being variable, granular and within cells showing no evidence of degeneration $\times 64()$.

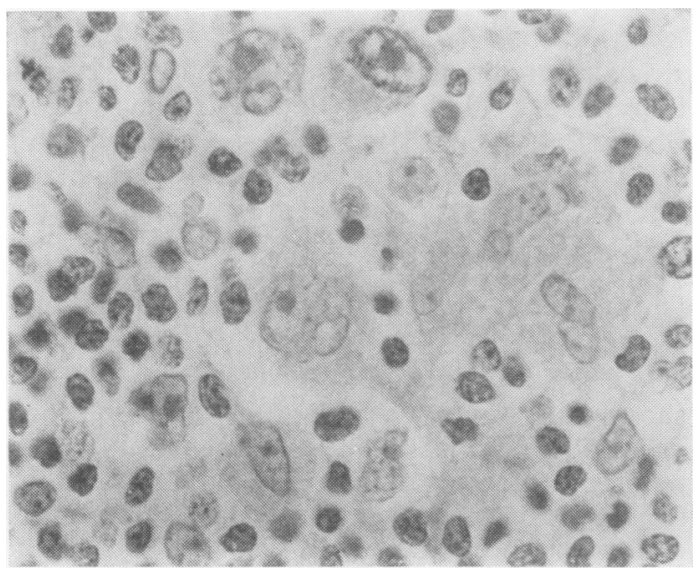

Fig. 3 Reed-Sternberg cells and mononuclear Hodgkin's cells fail to stain for $J$ chain $\times 640$.
IgD, C4, Clq and IgM. This is in agreement with other reports that these first three proteins are quite commonly detected in RS cells, ${ }^{16} 17$ but differs in finding IgM the least commonly detected protein. ${ }^{15} 16$ Poppema et al ${ }^{17}$ reported that albumin and $\alpha_{1} \mathrm{AT}$ were present in the same cells that contained IgG. In this study these proteins were found less frequently than IgG and their staining pattern differed in being non-granular and concentrated at the margin of the cell which usually showed morphological signs of degeneration. Together with the observation that the extent of staining for these proteins correlated with their molecular size it is suggested that they are passively acquired by dead or dying cells perhaps as a consequence of membrane damage. It is significant that viable RS cells in vitro do not contain albumin or fibrinogen. ${ }^{10}$

In all but three cases $\mathbf{J}$ chain was not present in RS cells. This polypeptide is associated with extra- 


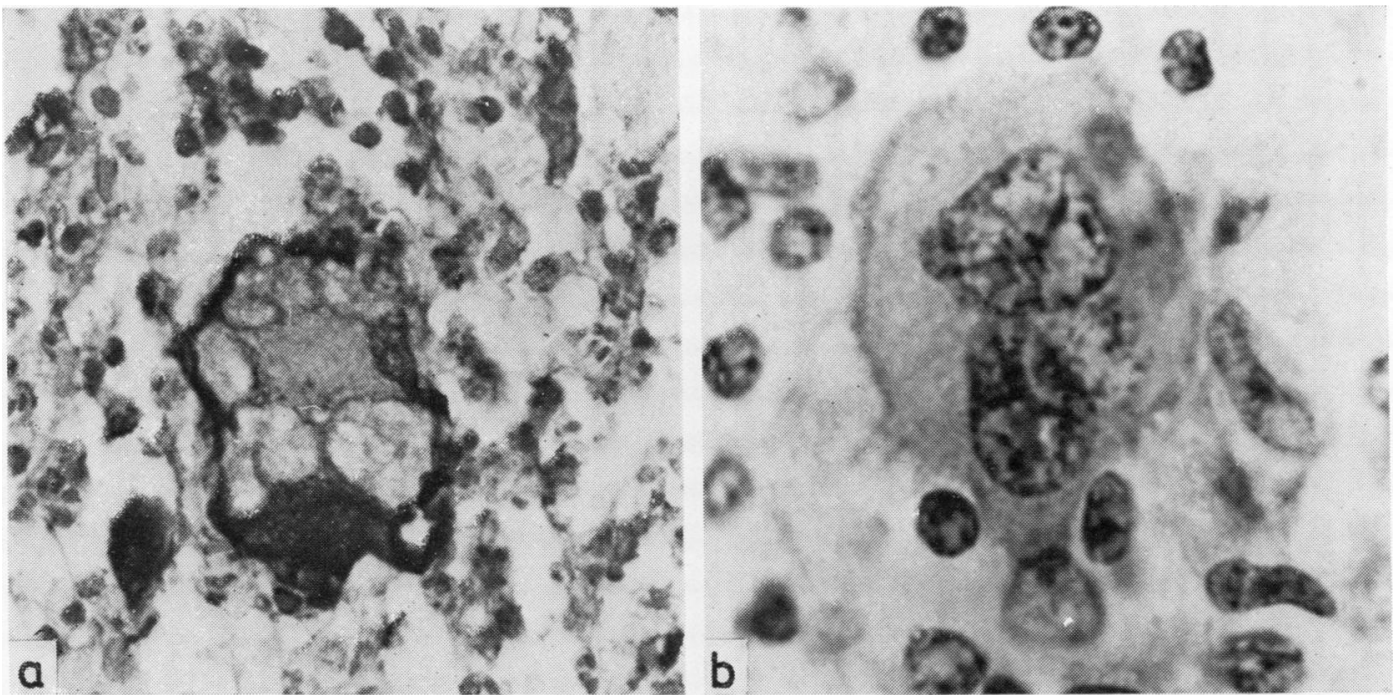

Fig. 4 Reed-Sternberg cells showing signs of degeneration staining for (a) IgG and (b) albumin. Staining is non-granular and more concentrated at the cell periphery. (a) $\times 640 ;(b) \times 2500$.

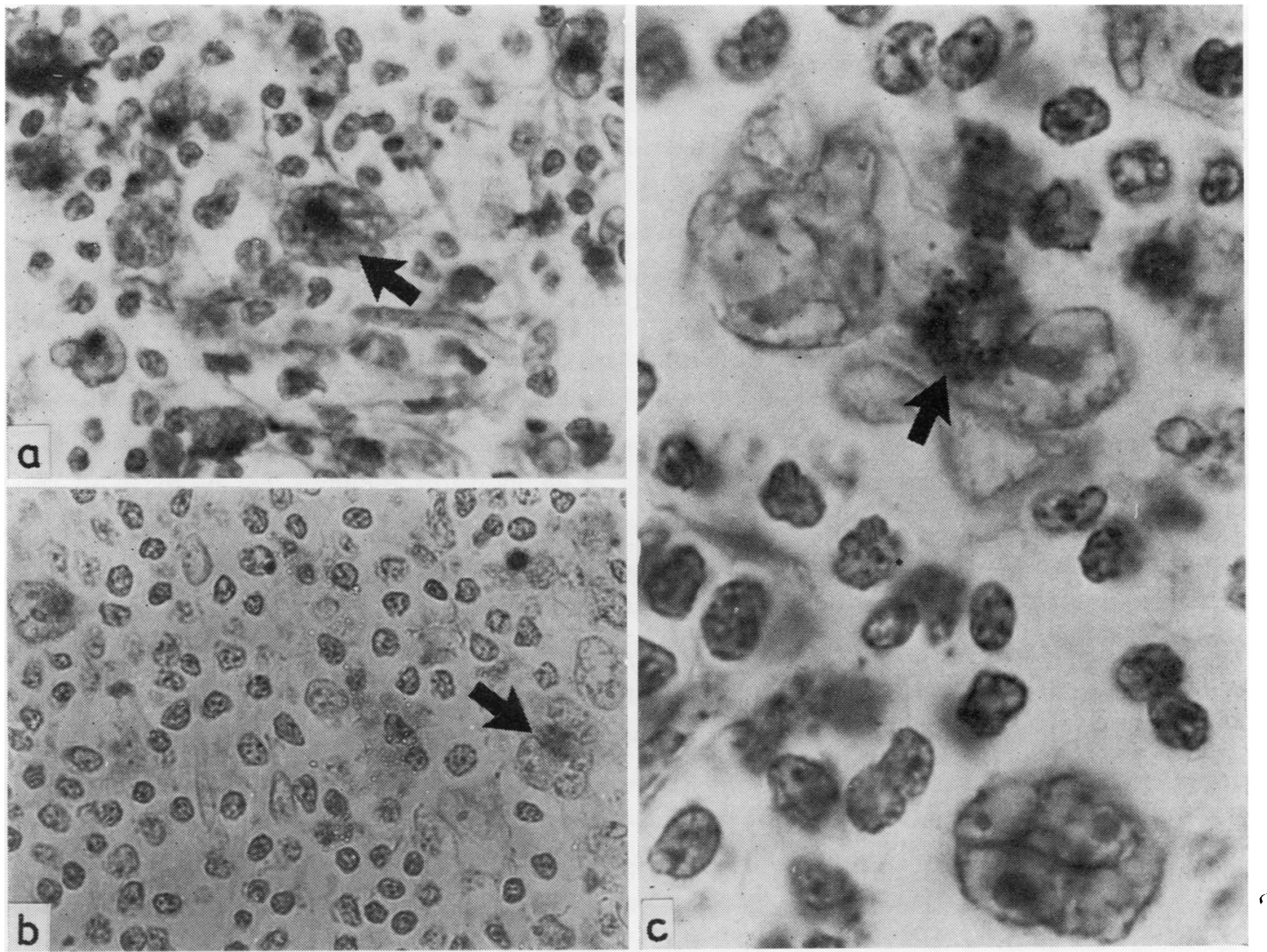

Fig. 5 Staining for $(a) a_{1} A T$ and (b) $a_{1} A C T$ in Reed-Sternberg and mononuclear Hodgkin's cells. (c) High power shows focal, granular nature of staining situated close to the nucleus or within a nuclear indentation (arrow) $(a)$ and $(b) \times 640 ;(c) \times 1600$. 


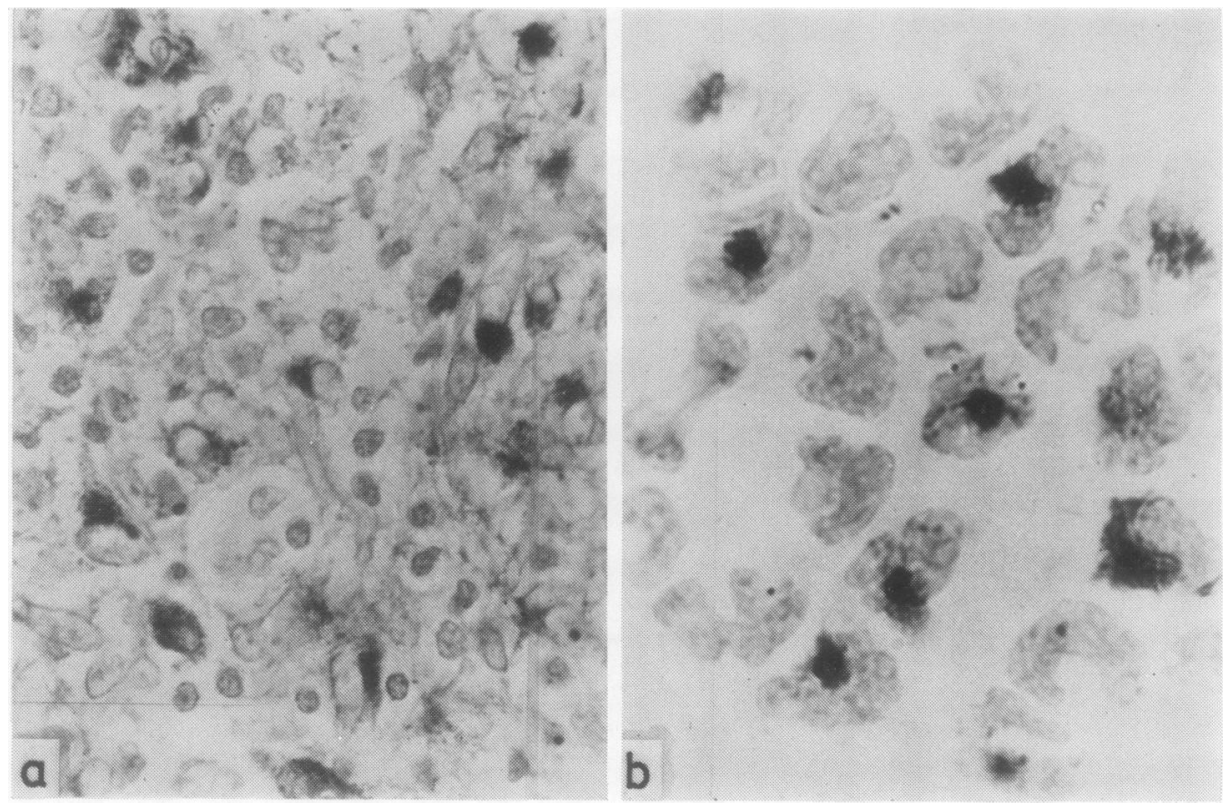

Fig. 6 Staining for $a_{1} A T$ in (a) reactive histiocytes in a Hodgkin's lymph node and (b) normal peripheral blood monocytes. Note focal, granular nature of stain. $(a) \times 640 ;(b) \times 1040$.

cellular dimeric IgA and $19 \mathrm{~S}$ IgM but not with IgG. Its synthesis, however, is not confined to $\operatorname{IgA}$ and IgM producing cells and may be found in normal and malignant cells producing immunoglobulin of all classes. ${ }^{20-22}$ The absence of $\mathbf{J}$ chain from $\gamma$ chainpositive RS cells suggests that IgG has not been synthesised by these cells but has been taken up from the extracellular environment. Very weak staining for $\mathbf{J}$ chain was seen in a few $\mathbf{R S}$ cells in three cases but it was accompanied by $\operatorname{IgA}$ - and $\operatorname{IgM}$-positive cells in two of these.

In addition to being more common the staining pattern for IgG differed from that of the other proteins in that it was granular, distributed evenly throughout the cytoplasm and was present in cells showing no morphological evidence of degeneration. It is suggested that it is acquired by a different mechanism from the other proteins and in view of the demonstration that RS cells in vitro can phagocytose immune complexes and internalise aggregated IgG, ${ }^{10}$ it is likely that a similar process, possibly involving $\mathrm{Fc} \gamma$ receptors, occurs in vivo. In support of an active uptake of serum IgG by RS cells is the observation that IgG is lost or reduced in RS cells during in vitro culture in the absence of human serum. ${ }^{27}$

The source of the IgG in RS cells in tissue sections is uncertain but the presence of circulating immune complexes in Hodgkin's patients may be relevant. ${ }^{2829}$
The basic reason why RS cells should take up and accumulate IgG remains unclear unless it is considered as the deranged function of a particular macrophage subset that is involved in the uptake or handling of immune complexes. This is in keeping with the suggestion that RS cells are related to dendritic reticulum cells. ${ }^{11}$ It is interesting that a derivation from the interdigitating reticulum cell of the $\mathrm{T}$ cell areas, has also been proposed ${ }^{30}$ a suggestion that is supported by the close association of autologous $\mathrm{T}$ cells with the RS cell surface. ${ }^{31}$

In addition to the diffuse staining for $\alpha_{1} \mathrm{AT}$ and $\alpha_{1}$ ACT seen in degenerating RS cells, an additional staining pattern for these protease inhibitors was found in viable RS cells in over half the cases studied. In these cases a variable number of RS cells showed staining for $\alpha_{1} \mathrm{AT}$ or $\alpha_{1} \mathrm{ACT}$, or both, as an accumulation of granules tucked into a nuclear indentation or situated close to the nucleus. Alpha1 -antitrypsin is present in polymorphonuclear leucocytes, platelets, monocytes and macrophages, ${ }^{24} 32-35$ pancreatic islet and acinar cells ${ }^{36} 37$ and in lymph node venule endothelial cells and kidney tubular epithelium (unpublished observations). It is not present within cells of the lymphocyte series although it may be associated with the surface of mitogen-activated lymphoblasts. ${ }^{38}$ The main site of synthesis of the serum protein is the liver but it has been suggested that platelets, pancreatic islet cells 
and macrophages may be capable of independent synthesis. ${ }^{24} 3439$ Whatever the origin of $\alpha_{1} \mathrm{AT}$ in normal monocytes and macrophages the nuclearorientated granular staining in immunoperoxidase preparations is characteristic of this lineage. The monocyte/macrophage origin of RS cells is supported by several lines of recent evidence including phagocytic activity and tissue culture properties. ${ }^{8-10}$ The expression of protease inhibitors in RS cells is variable as it is among normal monocytes and histiocytes. This variability may arise because they are the products of particular macrophage subsets, and it may be through studies of such macrophage subset markers that a clearer understanding of the nature of $\mathrm{RS}$ cells will emerge.

\section{References}

${ }^{1}$ Mori Y, Lennert K. Electron microscopic atlas of lymph node cytology and pathology. Berlin, Heidelberg, New York: Springer, 1969:29-30.

${ }^{2}$ Carr I. The ultrastructure of abnormal reticulum cells in Hodgkin's disease. J Pathol 1975;115:45-50.

${ }^{3}$ Dorfman RF, Rice DF, Mitchell AD, Kempson RL, Levine G. Ultrastructural studies of Hodgkin's disease. Natl Cancer Inst Monogr 1973;36:221-38.

${ }^{1}$ Glick AD, Leech JH, Flexner JM, Collins RD. Ultrastructural study of Reed-Sternberg cells. Am J Pathol 1976;85:195-200.

${ }^{5}$ Wright DH. Cytology and histochemistry of the malignant lymphomas seen in Uganda. Symposium on Lymphoreticular Tumours in Africa. Basel, New York: Karger, 1964:291-303.

${ }^{6}$ Stuart AE, Williams ARN, Habeshaw JA. Rosetting and other reactions of the Reed-Sternberg cell. J Pathol 1977;122:81-90.

7 Taylor CR. An immunohistological study of follicular lymphoma, reticulum cell sarcoma and Hodgkin's disease. Eur J Cancer 1976;12:61-75.

${ }^{8}$ Kaplan HS, Gartner S. "Sternberg-Reed" giant cells of Hodgkin's disease: cultivation in vitro; heterotransplantation and characterisation as neoplastic macrophages. Int J Cancer 1977;19:511-25.

${ }^{9}$ Roberts AN, Smith KL, Dowell BL, Hubbard AK. Cultural, morphological, cell membrane, enzymatic and neoplastic properties of cell lines derived from a Hodgkin's disease lymph node. Cancer Res 1978;38: 3033-43.

${ }^{10}$ Kadin ME, Stiles DP, Levy R, Warnke R. Exogenous immunoglobulin and the macrophage origin of ReedSternberg cells in Hodgkin's disease. $N$ Engl $\mathrm{J} \mathrm{Med}$ 1978;299:1208-14.

${ }^{11}$ Curran RC, Jones EL. Dendritic cells and B lymphocytes in Hodgkin's disease. Lancet 1977 ;ii:349.

12 Leech J. Immunoglobulin positive Reed-Sternberg cells in Hodgkin's disease. Lancet 1973 ; ii :265-6.

${ }^{13}$ Garvin AJ, Spicer SS, Parmley RT, Munster A M. Immunohistochemical demonstration of IgG in Reed-Sternberg and other cells in Hodgkin's disease. J Exp Med 1974; 139:1077-83.

14 Payne SV, Jones DB, Haegert DG, Smith JL, Wright DH. $T$ and $B$ lymphocytes and Reed-Sternberg cells in Hodgkin's disease lymph nodes and spleens. Clin Exp Immunol 1976;24:280-6.

${ }^{15}$ Landaas TO, Godal T, Halvorsen TB. Characterisation of immunoglobulins in Hodgkin's cells. Int $J$ Cancer 1977;20:717-22.

${ }^{16}$ Papadimitriou CS, Stein H, Lennert $\mathrm{K}$. The complexity of immunohistochemical staining pattern of Hodgkin and Sternberg-Reed cells-demonstration of immunoglobulin, albumin, alpha-1-antichymotrypsin and lysozyme. Int J Cancer 1978;21:531-41.

17 Poppema S, Elema JD, Halie MR. The significance of intracytoplasmic proteins in Reed-Sternberg cells. Cancer 1978;42:1793-1803.

18 Bernau D, Feldmann G, Vorhauer W. Hodgkin's disease: ultrastructural localisation of intracytoplasmic immunoglobulins within malignant cells. Br J Haematol 1978; 40:51-7.

19 Reynes M, Paczynski V, Galtier M, Diebold J. Ultrastructural synthesis in tumor cells in Hodgkin's disease. Int J Cancer 1979;23:474-81.

${ }^{20} \mathrm{Kaji} \mathrm{H}$, Parkhouse RME. Intracellular $\mathrm{J}$ chain in mouse plasmacytomas secreting IgA, IgM and IgG. Nature 1974;249:45-7.

21 Brandtzaeg P. Structural, functional and cellular studies of human J chain. Ric Clin Lab 1976;VI,3:15-38.

${ }^{22}$ Isaacson $\mathrm{P}$. Immunochemical demonstration of $\mathrm{J}$ chain: a marker of B cell malignancy. J Clin Pathol 1979;32: 802-7.

${ }^{23}$ Isaacson P, Wright DH, Judd MA, Mepham BL. Primary gastrointestinal lymphoma: a classification of 66 cases. Cancer 1979;43:1805-19.

${ }^{24}$ Isaacson P, Jones DB, Judd MA. Alpha-1-antitrypsin in human macrophages. Lancet 1979 ;ii:964-5.

25 Mepham BL, Frater W, Mitchell BS. The use of proteolytic enzymes to improve immunoglobulin staining by the PAP technique. Histochem J 1979;11:345-57.

26 Dalen Van JPR, Knapp W, Ploem JS. Microfluorimetry of antigen-antibody interaction of immunofluorescence using antigen covalently bound to agarose beads. $J$ Immunol Methods 1973;2:383-92.

27 Payne SV, Jones DB, Wright DH. Reed-Sternberg cell/ lymphocyte interaction. Lancet 1977;ii:768-9.

28 Amlot PL, Pussel B, Slaney JM, Williams BD. Correlation between immune complexes and prognostic factors in Hodgkin's disease. Clin Exp Immunol 1978;31:166-75.

28 Heier HE, Landaas TO, Marton PF. Circulating immune complexes and prognosis in human malignant lymphoma. A prospective study. Int J Cancer 1979;23:292-8.

${ }^{30}$ Lennert K, Kaiserling E, Muller-Hermelink HK Malignant lymphomas: models of differentiation and cooperation of lymphoreticular cells. In: Differentiation of normal and neoplastic hematopoietic cells. Cold Spring Harbor Conference on Cell Proliferation. 1978;5:897913.

31 Payne SV, Newell DG, Jones DB, Wright DH. The ReedSternberg cell/lymphocyte interaction. Ultrastructure and characteristics of binding. Am J Pathol 1980;100: 7-24.

32 Benitez L, Freyre R. Immunofluorescent localisation of alpha-1-antitrypsin in human polymorphonuclear leucocytes. Life Sci 1978;21:99-104.

${ }^{33}$ Nachman RL, Harpel PC. Platelet $\alpha_{2}$-macroglobulin and $a_{1}$-antitrypsin. J Biol Chem 1976;251:4515-21.

${ }^{34}$ Bagdasarian A, Colman RW. Subcellular localisation and

* purification of platelet $a_{1}$-antitrypsin. Blood 1978;51: 139-56.

${ }^{35}$ Cohen AB. Interrelationships between the human alveolar macrophage and alpha-1-antitrypsin. $J$ Clin Invest 1973;52:2793-99.

36 Ray MB, Desmet VJ, Gepts W. Alpha-1-antitrypsin immunoreactivity in islet cells of adult human pancreas. Cell Tissue Res 1977;185:63-8. 
37 Benjamin E, Wright DH. Adenocarcinoma of the pancreas of childhood: a report of two cases. Histopathology 1980;4:87-104.

${ }^{38}$ Lipsky JJ, Berninger RW, Hyman LR, Talamo RC. Presence of alpha-1-antitrypsin on mitogen-stimulated human lymphocytes. J Immunol 1979;122:24-6.

39 McElrath MJ, Galbraith RM, Allen RC. Demonstration of alpha-1-antitrypsin by immunofluorescence on paraffin-embedded hepatic and pancreatic tissue. $J$ Histochem Cytochem 1979;27:794-6.

Requests for reprints to: Professor DH Wright, Department of Pathology, Level E, South Pathology Block, Southampton General Hospital, Southampton SO9 4XY, England. 